\title{
Antileishmanial polyphenols from Corymbia maculata
}

\author{
JASMEEN SIDANA $^{\mathrm{a}, \dagger}$, DINESH NEERADI $^{\mathrm{b}}$, ALKA CHOUDHARY $^{\mathrm{a}}$, SUSHMA SINGH $^{\mathrm{b}}$, \\ WILLIAM J FOLEY ${ }^{\mathrm{c}}$ and INDER PAL SINGH ${ }^{\mathrm{a}, *}$ \\ ${ }^{a}$ Department of Natural Products, ${ }^{b}$ Department of Biotechnology, National Institute of Pharmaceutical \\ Education and Research (NIPER), Sector-67, SAS Nagar, Punjab 160 062, India \\ ${ }^{c}$ Research School of Biology, The Australian National University, Canberra 0200, Australia \\ †Present address: School of Pharmaceutical Sciences, Lovely Professional University, Phagwara, \\ Punjab 114 441, India \\ e-mail: ipsingh@niper.ac.in; ipsingh67@yahoo.com
}

MS received 5 December 2012; revised 22 February 2013; accepted 5 April 2013

\begin{abstract}
An activity-guided fractionation was used to identify the antileishmanial compounds of Corymbia maculata. The hexane, ethyl acetate and methanol extracts were active in in vitro antileishmanial assay. Twelve polyphenols including 8-demethyl eucalyptin (1), eucalyptin (2), myrciaphenone A (3), myrciaphenone B (4), quercetin-3- $O$ - $\beta$-D-xylopyranoside (5), myricetin-3- $O$ - $\alpha$-L-rhamnopyranoside (6), quercetin-3$O$ - $\beta$-D-galactopyranoside (7), quercetin-3-O- $\beta$-D-glucopyranoside (8), quercetin-3- $O$ - $\alpha$-L-rhamnopyranoside (9), syringic acid (10), gallic acid-3-methyl ether (11), gallic acid-4-methyl ether (12) and gallic acid (13) were isolated from the active extracts. All the tested compounds except 8-demethyleucalyptin and myrciaphenone B showed strong to moderate $(6.9-24.5 \mu \mathrm{M})$ antileishmanial activity against Leishmania donovani promastigotes. An HPLC-PDA method has been developed to detect/quantify 29 compounds in the extracts of C. maculata leaves. This validated method allows simultaneous quantitation of seven flavonoids, fourteen phloroglucinols and eight other polyphenols and can be applied for qualitative as well as quantitative determination of phytoconstituents in Eucalyptus matrices.
\end{abstract}

Keywords. Corymbia maculata; flavonoid glycosides; methylated flavonoids; myrciaphenone; HPLC quantitation.

\section{Introduction}

Leishmaniasis, one of the world's most neglected diseases, is endemic in 88 countries with more than 350 million people at risk. ${ }^{1}$ During the last few years, we have focused our interest on isolation and synthesis of potential antileishmanial molecules. ${ }^{2-4}$ In search of more bioactive constituents, we have investigated Corymbia maculata (Hook.) K D Hill and L A S Johnson (Syn: Eucalyptus maculata). Though several members of this genus have been the subject of extensive phytochemical and pharmacological research, reports of investigations on $C$. maculata are very few. Some methylated flavonoids isolated from $C$. maculata leaf extracts have shown antibacterial activity. ${ }^{5}$

In this paper, we report isolation of flavonoids and phenolics including 8-demethyl eucalyptin (1), ${ }^{6}$ eucalyptin (2), ${ }^{6}$ myrciaphenone A (3), ${ }^{7}$ myrciaphenone B (4), ${ }^{8}$ quercetin-3- $O$ - $\beta$-D-xylopyranoside (5), ${ }^{9}$

*For correspondence

NIPER communication no. 492. myricetin-3- $O$ - $\alpha$-L-rhamnopyranoside (6), ${ }^{10}$ quercetin3- $O$ - $\beta$-D-galactopyranoside (7), ${ }^{9}$ quercetin-3- $O$ - $\beta$-Dglucopyranoside (8), ${ }^{9}$ quercetin-3- $O$ - $\alpha$-L-rhamnopyranoside (9), ${ }^{9}$ syringic acid (10), ${ }^{11}$ gallic acid-3-methyl ether (11), ${ }^{12}$ gallic acid-4-methyl ether $(\mathbf{1 2})^{13}$ and gallic acid (13) ${ }^{14}$ (figure 1) from the extracts of leaves of $C$. maculata.

In addition, an RP-HPLC method was developed to detect and/or quantify formylated phloroglucinols and other compounds including flavonoids and simple phenols in the extracts of $C$. maculata. Although there have been several studies of the chemosystematics of the genus Eucalyptus, there are very few analytical methods available to simultaneously determine (qualitatively or quantitatively) the compounds belonging to diverse structural categories. The proposed HPLC method enables determination of eight formylated phloroglucinol compounds (including two monomerics, one dimeric and five euglobals), six 'nonformylated' phloroglucinols (including a monomer, two phloroglucinol glycosides and three triketones), seven flavonoids and eight other polyphenols. 


\section{Materials and methods}

\subsection{General}

All chemicals and solvents used for extraction and purification were of laboratory reagent grade. All chromatographic purifications were performed with silica gel \#60-120 and silica gel G whereas all TLC analysis was performed on silica gel coated (Merck Kieselgel $60 \mathrm{~F}_{254}, 0.2 \mathrm{~mm}$ thickness) plates. HPLC grade ethyl acetate, acetonitrile, methanol, formic acid, acetic acid and trifluoroacetic acid (JT Baker) and ultra pure water $(\mathrm{Elga} \cap)$ were used for sample preparation and in HPLC mobile phases.

Apart from the chemical markers isolated from C. maculata (1-13), the standards i.e., protocatechuic acid (14), chlorogenic acid (15), caffeic acid (16), 2-hydroxycinnamic acid (17) were a kind gift from Prof. R C Gupta of University of Louisville, USA. Miniatone (20), grandinol (21), 8-demethyl kalmiatin (22), jensenone (23), euglobal G1 (25), sideroxylonal A (26), euglobal G2 (27), euglobal Bl-1 (28), euglobal G3 (29), euglobal G4 (30) were isolated from different sources. ${ }^{4,15}$ Syncarpic acid (18), flavesone (19) and leptospermone (24) were synthesized from phloroglucinol (for structures, see figure 1). All the standards were $\geq 98 \%$ pure by HPLC and NMR.

\subsection{Plant material}

The plant material was collected from four individual trees at the Australian National University coastal campus Kioloa, New South Wales, Australia. The leaves

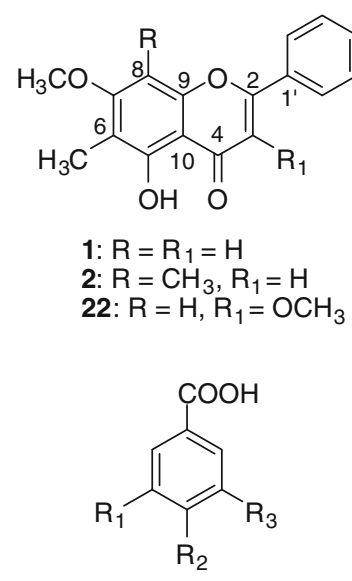

10: $\mathrm{R}_{1}=\mathrm{R}_{3}=\mathrm{OCH}_{3}, \mathrm{R}_{2}=\mathrm{OH}$

11: $\mathrm{R}_{1}=\mathrm{OCH}_{3}, \mathrm{R}_{2}=\mathrm{R}_{3}=\mathrm{OH}$

12: $R_{1}=R_{3}=O H, R_{2}=O_{3}$

13: $\mathrm{R}_{1}=\mathrm{R}_{2}=\mathrm{R}_{3}=\mathrm{OH}$

14: $R_{1}=R_{2}=O H, R_{3}=H$<smiles>[R]C(=O)C1=C(O)C(C)(C)C(=O)C(C)(C)C1=O</smiles>

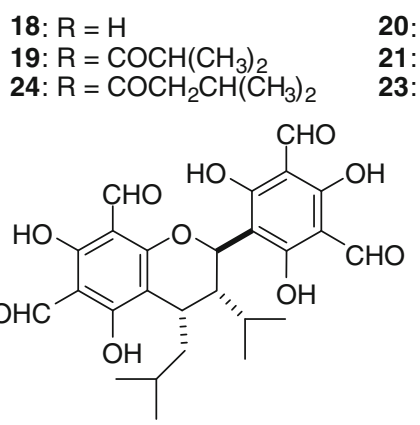

26

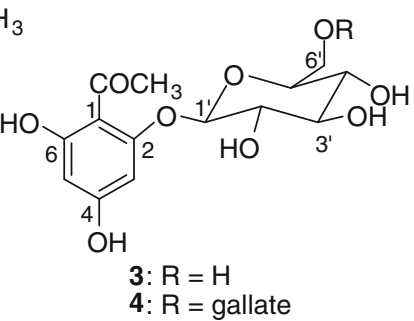<smiles>O=C(/C=C/c1ccc(O)c(O)c1)O[C@@H]1C[C@](O)(C(=O)O)C[C@H](O)[C@H]1O</smiles>

15<smiles>[R6]Oc1c([R6])c(O)c(C(=O)CC(C)C)c([R6])c1O</smiles>

20: $\mathrm{R}_{1}=\mathrm{R}_{2}=\mathrm{R}_{3}=\mathrm{R}_{4}=\mathrm{CH}_{3}$

21: $\mathrm{R}_{1}=\mathrm{CH}_{3}, \mathrm{R}_{2}=\mathrm{CHO}, \mathrm{R}_{3}=\mathrm{R}_{4}=\mathrm{H}$

23: $R_{1}=R_{2}=C H O, R_{3}=R_{4}=H$<smiles>CC(C)CC1C[C@]2(CC[C@@H]3CC[C@H]2C3)Oc2c(O)c(O)c(C=O)c(C=O)c21</smiles>

28<smiles>[R7]c1cc(-c2oc3cc(O)cc(O)c3c(=O)c2[R])cc(O)c1O</smiles>

5: $\mathrm{R}=$ xylopyranoside, $\mathrm{R}_{1}=\mathrm{H}$

6: $\mathrm{R}=\alpha$-L-rhamnopyranoside, $\mathrm{R}_{1}=\mathrm{OH}$

7: $\mathrm{R}=\beta$-D-galactopyranoside, $\mathrm{R}_{1}=\mathrm{H}$

8: $\mathrm{R}=\beta$-D-glucopyranoside, $\mathrm{R}_{1}=\mathrm{H}$

9: $\mathrm{R}=\alpha$-L-rhamnopyranoside, $\mathrm{R}_{1}=\mathrm{H}$<smiles>[R5]c1ccc(/C=C/C(=O)O)c(Br)c1[R6]</smiles>

16: $\mathrm{R}_{1}=\mathrm{H}, \mathrm{R}_{2}=\mathrm{R}_{3}=\mathrm{OH}$

17: $R_{1}=O H, R_{2}=R_{3}=H$

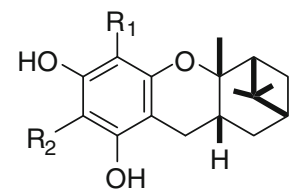

25: $\mathrm{R}_{1}=\mathrm{CHO}, \mathrm{R}_{2}=\mathrm{COCH}_{2} \mathrm{CH}\left(\mathrm{CH}_{3}\right)_{2}$ 27: $\mathrm{R}_{1}=\mathrm{COCH}_{2} \mathrm{CH}\left(\mathrm{CH}_{3}\right)_{2}, \mathrm{R}_{2}=\mathrm{CHO}$<smiles>[R2]c1c(O)c([R])c2c(c1O)CC[C@@]1(CC3C4C5C3C4C51)O2</smiles>

29: $\mathrm{R}_{1}=\mathrm{CHO}, \mathrm{R}_{2}=\mathrm{COCH}_{2} \mathrm{CH}\left(\mathrm{CH}_{3}\right)_{2}$ 30: $\mathrm{R}_{1}=\mathrm{COCH}_{2} \mathrm{CH}\left(\mathrm{CH}_{3}\right)_{2}, \mathrm{R}_{2}=\mathrm{CHO}$

Figure 1. Structures of compounds 1-30. 
were air-dried in the shade, crushed coarsely and stored at $-20^{\circ} \mathrm{C}$ until extraction.

\subsection{Equipment and apparatus}

The HPLC analysis was carried out on $\mathrm{C}_{18}$ column (Phenomenex, $250 \times 4.6 \mathrm{~mm}, 5 \mu, 100 \AA$ ) connected to a Shimadzu HPLC system consisting of a model LC-10AT VP fitted with a SIL-20AC autosampler and SPD-M10A VP photodiode array detector. Princeton SPHER-C ${ }_{18}$ column $(250 \times 10 \mathrm{~mm}, 5 \mu, 100 \AA)$ was used for isolation of compounds.

Isolation of compounds was also done using $\mathrm{C}_{18}$ column (Luna, $250 \times 30 \mathrm{~mm}, 10 \mu, 100 \AA$ ) connected to a preparative HPLC system (Shimadzu, CBM-20A) equipped with a LC-8A binary gradient pump, an SPD20AV UV-Vis detector, an FRC-10A fraction collector and a recycle valve.

IR spectra were taken on FT-IR spectrometer (Nicolet, USA). Mass spectra were recorded on a GCMS-QS (Shimadzu, Japan). ${ }^{1} \mathrm{H}$ and ${ }^{13} \mathrm{C}$ NMR spectra were recorded on 400 and $100 \mathrm{MHz}$ spectrometers (Bruker), respectively.

\subsection{Extraction and isolation}

Dried and crushed leaves $(2 \mathrm{~kg})$ of $C$. maculata were extracted in a macerator (20 L capacity) with hexane $(5 \mathrm{~L} \times 5)$ for $48 \mathrm{~h}$. The extract was filtered to remove any plant particles and was concentrated on rotary evaporator to yield $47 \mathrm{~g}$ of thick yellowish-green tar. Similarly, leaves were sequentially extracted with solvents in increasing polarity to yield $42 \mathrm{~g}$ of dichloromethane, $56 \mathrm{~g}$ of ethyl acetate and $80 \mathrm{~g}$ of methanol extract.

Light yellow crystals separated out of hexane extract while it was being concentrated. These were washed several times with cold hexane and dried. This fraction $(7.8 \mathrm{~g})$ showed only one major spot apart from chlorophylls on normal phase TLC developed with hexaneDCM (1:1). It was subjected to charcoal treatment to remove plant pigments. A portion $(100 \mathrm{mg})$ of this fraction was subjected to semi-preparative HPLC [column: $\mathrm{C}_{18}, 250 \times 10 \mathrm{~mm}$; mobile phase: methanol- $0.3 \%$ aqueous trifluoroacetic acid (9:1); Flow rate: $3.5 \mathrm{~mL} \cdot \mathrm{min}^{-1}$; detection: $328 \mathrm{~nm}$ ] to yield compound $\mathbf{1}(17 \mathrm{mg})$ and compound 2 ( $52 \mathrm{mg}$ ).

Methanol extract $(80 \mathrm{~g})$ was partitioned into dichloromethane (trace), ethyl acetate (20 g) and butanol $(55 \mathrm{~g})$ soluble fractions. The butanol-soluble fraction was chromatographed over silica gel \#60-120 [column H: $30 \mathrm{~cm}$, i.d.: $7 \mathrm{~cm}$; eluant: hexane-ethyl acetate $(0 \%$ to $90 \%$ EtOAc) then chloroformmethanol gradients $(1 \%$ to $50 \% \mathrm{MeOH})]$ to yield 15 sub-fractions.

Pooled sub-fractions 5 and 6 (6.3 g, eluted with $5-10 \%$ methanol in chloroform) were subjected to gel permeation chromatography over Sephadex LH20 using methanol to obtain six pools of different TLC profiles. Pools 3 and $4(1.0 \mathrm{~g})$ were subjected to recycle prep-HPLC [column: $\mathrm{C}_{18}, 250 \times 30 \mathrm{~mm}$; mobile phase: methanol-water-acetic acid (30:69:1); flow rate: $40 \mathrm{~mL} \cdot \mathrm{min}^{-1}$; detection: $284 \mathrm{~nm}$ ] to obtain compounds $\mathbf{3}(880 \mathrm{mg})$ and $\mathbf{4}(18 \mathrm{mg})$. Pool 5 (800 mg) stained yellow to orange with natural products (NP) reagent revealing the presence of flavonoids. Repetitive and recycle chromatography of this fraction [column: $\mathrm{C}_{18}, 250 \times 30 \mathrm{~mm}$; mobile phase: methanol-wateracetic acid (40:59:1); flow rate: $40 \mathrm{~mL} \cdot \mathrm{min}^{-1}$; detection: $350 \mathrm{~nm}$ ] gave compounds $5(17 \mathrm{mg}), \mathbf{6}(55 \mathrm{mg})$, 7 (20 mg), 8 (5 mg) and 9 (145 mg).

Pooled sub-fractions 8 and 9 (16.3 g, eluted with $20 \%$ methanol in chloroform) were subjected to gel permeation chromatography over Sephadex LH20 using methanol to obtain 5 fractions. Fraction 3 (2.95 g) presented two major spots (giving intense blue fluorescence with NP reagent) on normal phase TLC developed with toluene-ethyl acetate-acetic acid (5:4.5:0.5). A portion of this fraction was rechromatographed over Sephadex LH20 using methanol-water (1:1) to yield compounds $\mathbf{1 0}(25 \mathrm{mg}), \mathbf{1 1}(48 \mathrm{mg}), \mathbf{1 2}(13 \mathrm{mg})$ and $13(1.1 \mathrm{~g})$.

2.4a Compound 1: Light yellow crystals, IR (Neat): $v_{\max } 3391,2923,2953,2868,1605,1459,1376,1219$, $1054 \mathrm{~cm}^{-1}$; APCI MS: $m / z 313[\mathrm{M}+1]^{+}, 298,236$, $165 ;{ }^{1} \mathrm{H}$ and ${ }^{13} \mathrm{C}$ NMR $\left(400 \mathrm{MHz}, \mathrm{CDCl}_{3}\right)$ : see table 1a.

2.4b Compound 2: Light yellow needles; IR (Neat): $v_{\max } 3400,2924,2851,1634,1459,1376,1219$, $1053 \mathrm{~cm}^{-1}$; APCI MS: $m / z 327[\mathrm{M}+1]^{+}, 313[\mathrm{M}-$ $\left.\mathrm{CH}_{3}\right]^{+}, 236,165 ;{ }^{1} \mathrm{H}$ and ${ }^{13} \mathrm{C} \mathrm{NMR}\left(400 \mathrm{MHz}, \mathrm{CDCl}_{3}\right.$ ): see table 1a.

2.4c Compound 3: Off white solid; IR (Neat): $v_{\max }$ 3368, 2946, 2833, 1654, 1453, 1414, 1114, 1032, $668 \mathrm{~cm}^{-1}$; APCI MS: $m / z 353[\mathrm{M}+\mathrm{Na}]^{+}, 316,302$, 202 sugar $+\mathrm{Na}]^{+}, 168 ;{ }^{1} \mathrm{H}$ and ${ }^{13} \mathrm{C}$ NMR $(400 \mathrm{MHz}$, $\mathrm{CD}_{3} \mathrm{OD}$ ): see table $1 \mathrm{a}$.

2.4d Compound 4: Light brown solid; IR (Neat): $v_{\max } 3435,2973,2923,2866,1638,1360,1054$, 1033, 1016, $766 \mathrm{~cm}^{-1}$; APCI MS: $m / z 505[\mathrm{M}+\mathrm{Na}]^{+}$, 
Table 1a. ${ }^{1} \mathrm{H}(\delta$ ppm, multiplicity, $J$ in $\mathrm{Hz})$ and ${ }^{13} \mathrm{C}(\delta$ ppm $)$ NMR data of compounds $\mathbf{1 - 4}$.

\begin{tabular}{|c|c|c|c|c|c|c|c|c|}
\hline \multirow[b]{2}{*}{ Position } & \multicolumn{2}{|c|}{1} & \multicolumn{2}{|c|}{2} & \multicolumn{2}{|r|}{3} & \multicolumn{2}{|r|}{4} \\
\hline & $\delta_{\mathrm{C}}$ & $\delta_{\mathrm{H}}$ & $\delta_{\mathrm{C}}$ & $\delta_{\mathrm{H}}$ & $\delta_{\mathrm{C}}$ & $\delta_{\mathrm{H}}$ & $\delta_{\mathrm{C}}$ & $\delta_{\mathrm{H}}$ \\
\hline 1 & & & & & 105.3 & & 105.5 & \\
\hline 2 & 163.4 & & 162.6 & & 164.8 & & 161.2 & \\
\hline 3 & 105.3 & $6.59, \mathrm{~s}$ & 107.4 & $6.61, \mathrm{~s}$ & 100.6 & $6.18, \mathrm{~d}, 2.0$ & 94.3 & $6.16, \mathrm{~s}$ \\
\hline 4 & 182.4 & & 183.2 & & 166.3 & & 165.0 & \\
\hline 5 & 158.5 & & 157.3 & & 93.9 & $5.94, \mathrm{~d}, 2.0$ & 97.0 & $5.94, \mathrm{~s}$ \\
\hline 6 & 114.1 & & 114.1 & & 161.2 & & 166.2 & \\
\hline 7 & 163.6 & & 163.9 & & 203.4 & & 203.4 & \\
\hline 8 & 89.3 & $6.49, \mathrm{~s}$ & 104.1 & & 32.1 & $2.68, \mathrm{~s}$ & 32.0 & $2.67, \mathrm{~s}$ \\
\hline 9 & 155.9 & & 152.9 & & & & & \\
\hline 10 & 109.1 & & 108.8 & & & & & \\
\hline $1^{\prime}$ & 123.8 & & 123.9 & & 96.7 & $5.01, \mathrm{~d}, 7.4$ & 100.8 & $5.07, d, 7.6$ \\
\hline $2^{\prime}$ & 127.9 & $7.84, \mathrm{~d}, 8.0$ & 127.9 & $7.86, \mathrm{~d}, 8.4$ & 73.3 & $\begin{array}{l}3.72, \mathrm{dd} \\
12.0,5.2\end{array}$ & 73.3 & $3.75-3.48, \mathrm{~m}$ \\
\hline $3^{\prime}$ & 114.5 & $7.01, \mathrm{~d}, 8.8$ & 114.5 & $7.02, \mathrm{~d}, 8.4$ & 77.1 & $3.55-3.34, \mathrm{~m}$ & 76.8 & \\
\hline $4^{\prime}$ & 162.5 & & 162.6 & & 69.7 & & 69.7 & \\
\hline $5^{\prime}$ & 114.5 & $7.01, \mathrm{~d}, 8.8$ & 114.5 & $7.02, \mathrm{~d}, 8.4$ & 76.9 & & 74.4 & \\
\hline $6^{\prime}$ & 127.9 & $7.84, \mathrm{~d}, 8.0$ & 127.9 & $7.86, \mathrm{~d}, 8.4$ & 60.9 & $\begin{array}{l}3.91, \mathrm{dd} \\
12.0,1.6\end{array}$ & 62.9 & $\begin{array}{c}4.55, \mathrm{~d}, 12.0 \\
\text { and } 4.45, \mathrm{dd}, \\
12.0,4.4\end{array}$ \\
\hline $1^{\prime \prime}$ & & & & & & & 119.8 & \\
\hline $2^{\prime \prime}$ & & & & & & & 108.8 & $7.10, \mathrm{~s}$ \\
\hline $3^{\prime \prime}$ & & & & & & & 145.1 & \\
\hline $4^{\prime \prime}$ & & & & & & & 138.5 & \\
\hline $5^{\prime \prime}$ & & & & & & & 145.1 & \\
\hline $6^{\prime \prime}$ & & & & & & & 108.8 & $7.10, \mathrm{~s}$ \\
\hline $7^{\prime \prime}$ & & & & & & & 166.9 & \\
\hline $7 / 4^{\prime}-\mathrm{OCH}_{3}$ & $55.9 / 55.5$ & $3.89 / 3.92, \mathrm{~s}$ & $60.5 / 55.5$ & $3.89 / 3.79, \mathrm{~s}$ & & & & \\
\hline $6 / 8-\mathrm{CH}_{3}$ & 7.3 & $2.11, \mathrm{~s}$ & $8.5 / 8.2$ & $2.39 / 2.21, \mathrm{~s}$ & & & & \\
\hline
\end{tabular}

$482[\mathrm{M}]^{+}, 315 ;{ }^{1} \mathrm{H}$ and ${ }^{13} \mathrm{C} \mathrm{NMR}\left(400 \mathrm{MHz}, \mathrm{CD}_{3} \mathrm{OD}\right)$ : see table 1a.

2.4e Compound 5: Yellow solid; IR (Neat): $v_{\max }$ 3411, 2950, 2844, 1642, 1053, 1032, $1016 \mathrm{~cm}^{-1}$; APCI MS: $m / z 457[\mathrm{M}+\mathrm{Na}]^{+}, 303[\mathrm{M} \text {-sugar }]^{+} ;{ }^{1} \mathrm{H}$ and ${ }^{13} \mathrm{C}$ NMR (400 MHz, $\left.\mathrm{CD}_{3} \mathrm{OD}\right)$ : see table $1 \mathrm{~b}$.

2.4f Compound 6: Light yellow solid; IR (Neat): $v_{\max } 3368,2946,2833,1654,1453,1415,1116,1031$, $667 \mathrm{~cm}^{-1}$; APCI MS: $m / z 487[\mathrm{M}+\mathrm{Na}]^{+}, 464[\mathrm{M}]^{+}$, 319 [M-sugar $]^{+} ;{ }^{1} \mathrm{H}$ and ${ }^{13} \mathrm{C} \mathrm{NMR}\left(400 \mathrm{MHz}, \mathrm{CD}_{3} \mathrm{OD}\right)$ : see table $1 b$.

2.4g Compound 7: Yellow solid; IR (Neat): $v_{\max }$ 3433, 2920, 1745, 1683, 1598, 1053, $1075 \mathrm{~cm}^{-1}$; APCI MS: $m / z 487[\mathrm{M}+\mathrm{Na}]^{+}, 465[\mathrm{M}+1]^{+}, 303[\mathrm{M} \text {-sugar }]^{+}$; ${ }^{1} \mathrm{H}$ and ${ }^{13} \mathrm{C}$ NMR $\left(400 \mathrm{MHz}, \mathrm{CD}_{3} \mathrm{OD}\right)$ : see table $1 \mathrm{~b}$.

2.4h Compound 8: Yellow solid; IR (Neat): $v_{\max }$ $3433,2920,1745,1683,1598,1053,1075 \mathrm{~cm}^{-1}$; APCI

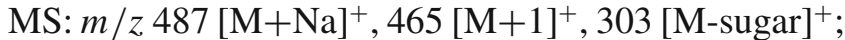
${ }^{1} \mathrm{H}$ and ${ }^{13} \mathrm{C}$ NMR (400 MHz, $\mathrm{CD}_{3} \mathrm{OD}$ ): see table $1 \mathrm{~b}$.

2.4i Compound 9: Light yellow solid; IR (Neat): $v_{\max } 3435,2972,2844,1645,1372,1054,1032$, 1015, $772 \mathrm{~cm}^{-1}$; APCI MS: $m / z 471[\mathrm{M}+\mathrm{Na}]^{+}, 449$ $[\mathrm{M}+\mathrm{H}]^{+}, 303$ [M-sugar ${ }^{+} ;{ }^{1} \mathrm{H}$ and ${ }^{13} \mathrm{C}$ NMR $(400 \mathrm{MHz}$, $\mathrm{CD}_{3} \mathrm{OD}$ ): see table $1 \mathrm{~b}$.

2.4j Compound 10: Colourless needles (MeOH); IR (Neat): $v_{\max }$ 3474, 2941, 1698, 1617, 1521, 1372, 1203, $1177,1113 \mathrm{~cm}^{-1}$; APCI MS: $m / z 181[\mathrm{M}-\mathrm{OH}]^{+}, 154$; ${ }^{1} \mathrm{H}$ NMR (400 MHz, $\left.\mathrm{CD}_{3} \mathrm{OD}\right): \delta 7.33(2 \mathrm{H}, \mathrm{s}, \mathrm{H}-2,-6)$, $3.88\left(6 \mathrm{H}, \mathrm{s}, 3,5-\mathrm{OCH}_{3}\right) ;{ }^{13} \mathrm{C}$ NMR $(100 \mathrm{MHz}$, $\left.\mathrm{CD}_{3} \mathrm{OD}\right): \delta 170.1(-\mathrm{COOH}), 148.8(\mathrm{C}-3,-5), 141.7$ $(\mathrm{C}-4), 121.9(\mathrm{C}-1), 108.3(\mathrm{C}-2,-6), 56.8\left(3,5-\mathrm{OCH}_{3}\right)$.

2.4k Compound 11: Light yellow needles $(\mathrm{MeOH})$; IR (Neat): $v_{\max } 3434,2920,1660,1613,1346,1313$, 1255, 1111, $1082 \mathrm{~cm}^{-1}$; APCI MS: $m / z 167[\mathrm{M}-\mathrm{OH}]^{+}$; ${ }^{1} \mathrm{H}$ NMR $\left(400 \mathrm{MHz}, \mathrm{CD}_{3} \mathrm{OD}\right): \delta 7.11(1 \mathrm{H}, \mathrm{s}, \mathrm{H}-2)$, 
Table 1b. ${ }^{1} \mathrm{H}(\delta$ ppm, multiplicity, $J$ in $\mathrm{Hz})$ and ${ }^{13} \mathrm{C}$ NMR $(\delta$ ppm $)$ data of compounds 5-9.

\begin{tabular}{|c|c|c|c|c|c|c|c|c|c|c|}
\hline \multirow[b]{2}{*}{ Position } & \multicolumn{2}{|r|}{5} & \multicolumn{2}{|r|}{6} & \multicolumn{2}{|r|}{7} & \multicolumn{2}{|r|}{8} & \multicolumn{2}{|r|}{9} \\
\hline & $\delta_{\mathrm{C}}$ & $\delta_{\mathrm{H}}$ & $\delta_{\mathrm{C}}$ & $\delta_{\mathrm{H}}$ & $\delta_{\mathrm{C}}$ & $\delta_{\mathrm{H}}$ & $\delta_{\mathrm{C}}$ & $\delta_{\mathrm{H}}$ & $\delta_{\mathrm{C}}$ & $\delta_{\mathrm{H}}$ \\
\hline 2 & 157.0 & & 158.0 & & 156.7 & & 158.5 & & 157.1 & \\
\hline 3 & 134.0 & & 134.9 & & 133.9 & & 135.7 & & 134.8 & \\
\hline 4 & 178.0 & & 178.2 & & 177.9 & & 179.5 & & 179.6 & \\
\hline 5 & 161.6 & & 161.8 & & 156.6 & & 159.1 & & 157.9 & \\
\hline 6 & 98.5 & $6.20, \mathrm{~s}$ & 98.4 & $6.19, \mathrm{~s}$ & 99.1 & $6.22, \mathrm{~s}$ & 100.0 & $6.22, \mathrm{~s}$ & 98.4 & $6.20, \mathrm{~s}$ \\
\hline 7 & 164.6 & & 164.5 & & 164.6 & & 166.0 & & 164.5 & \\
\hline 8 & 93.3 & $6.39, \mathrm{~s}$ & 93.3 & $6.36, \mathrm{~s}$ & 93.9 & $6.43, \mathrm{~s}$ & 94.9 & $6.42, \mathrm{~s}$ & 93.3 & $6.37, \mathrm{~s}$ \\
\hline 9 & 157.5 & & 157.1 & & 161.7 & & 162.9 & & 161.8 & \\
\hline 10 & 104.2 & & 104.4 & & 104.3 & & 105.7 & & 104.5 & \\
\hline $1^{\prime}$ & 121.6 & & 120.5 & & 121.5 & & 123.1 & & 121.4 & \\
\hline $2^{\prime}$ & 114.6 & $7.58, \mathrm{~d}, 8.8$ & 108.1 & $7.00, \mathrm{~s}$ & 115.6 & $7.84, \mathrm{~s}$ & 116.1 & $7.71, \mathrm{~s}$ & 114.9 & $7.33, \mathrm{~s}$ \\
\hline $3^{\prime}$ & 144.6 & & 145.4 & & 145.3 & & 145.9 & & 145.0 & \\
\hline $4^{\prime}$ & 148.5 & & 136.5 & & 148.9 & & 149.9 & & 148.4 & \\
\hline $5^{\prime}$ & 115.8 & $6.86, \mathrm{~d}, 8.4$ & 145.4 & & 116.4 & $6.88, \mathrm{~d}, 8.8$ & 117.7 & $6.88, \mathrm{~d}, 8.4$ & 115.5 & $6.90, \mathrm{~d}, 8.0$ \\
\hline $6^{\prime}$ & 121.9 & $7.61, \mathrm{~s}$ & 108.1 & $7.00, \mathrm{~s}$ & 122.4 & $7.59, \mathrm{~d}, 8.7$ & 123.3 & $7.59, \mathrm{~d}, 8.4$ & 121.5 & $7.30, \mathrm{~d}, 8.4$ \\
\hline $1^{\prime \prime}$ & 103.2 & $5.17, \mathrm{~d}, 7.2$ & 102.2 & $5.32, \mathrm{~s}$ & 102.2 & $5.17, \mathrm{~d}, 8.0$ & 104.5 & $5.24, \mathrm{~d}, 7.2$ & 102.1 & $5.34, \mathrm{~s}$ \\
\hline $2^{\prime \prime}$ & 73.8 & $3.51-3.41, \mathrm{~m}$ & 70.5 & $4.23, \mathrm{~s}$ & 71.6 & $3.56, \mathrm{~m}$ & 75.8 & $3.47-3.35, \mathrm{~m}$ & 70.5 & $4.21, \mathrm{~s}$ \\
\hline $3^{\prime \prime}$ & 69.6 & & 70.6 & $3.79, \mathrm{~d}, 8.4$ & 76.3 & & 78.4 & & 70.6 & $3.74, \mathrm{dd}, 9.2,1.2$ \\
\hline $4^{\prime \prime}$ & 76.1 & & 71.9 & $3.34, \mathrm{~m}$ & 68.4 & $3.48, \mathrm{~m}$ & 71.3 & & 71.8 & $3.45-3.38, \mathrm{~m}$ \\
\hline $5^{\prime \prime}$ & 65.8 & $\begin{array}{l}3.78, \mathrm{dd}, 11.5, \\
5.1 \text { and } 3.10, \mathrm{~m}\end{array}$ & 70.7 & $3.52, \mathrm{~m}$ & 73.6 & $3.35, \mathrm{~m}$ & 78.1 & $3.22, \mathrm{~m}$ & 70.7 & \\
\hline $6^{\prime \prime}$ & & & 16.3 & $0.98, \mathrm{~d}, 6.4$ & 60.6 & $\begin{array}{c}3.83, \mathrm{~m} \text { and } \\
3.64, \mathrm{~m}\end{array}$ & 62.6 & $\begin{array}{l}3.73, \mathrm{~m} \text { and } \\
3.57, \mathrm{~m}\end{array}$ & 16.2 & $0.94, \mathrm{~d}, 6.0$ \\
\hline
\end{tabular}

$7.09(1 \mathrm{H}, \mathrm{s}, \mathrm{H}-6), 3.78\left(3 \mathrm{H}, \mathrm{s}, 3-\mathrm{OCH}_{3}\right) ;{ }^{13} \mathrm{C} \mathrm{NMR}$ $\left(100 \mathrm{MHz}, \mathrm{CD}_{3} \mathrm{OD}\right): \delta 170.4(-\mathrm{COOH}), 149.1(\mathrm{C}-3)$, 146.1 (C-5), 140.5 (C-4), 121.9 (C-1), 112.2 (C-6), $106.3(\mathrm{C}-2), 56.8\left(3-\mathrm{OCH}_{3}\right)$.

2.41 Compound 12: Light yellow needles $(\mathrm{MeOH})$; IR (Neat): $v_{\max } 3374,1698,1613,1535,1443,1329$, 1260, 1212, $1053 \mathrm{~cm}^{-1}$; APCI MS: $m / z 167[\mathrm{M}-\mathrm{OH}]^{+}$; ${ }^{1} \mathrm{H}$ NMR (400 MHz, $\left.\mathrm{CD}_{3} \mathrm{OD}\right): \delta 7.03(2 \mathrm{H}, \mathrm{s}, \mathrm{H}-2,-6)$, $3.80\left(3 \mathrm{H}, \mathrm{s}, 4-\mathrm{OCH}_{3}\right) ;{ }^{13} \mathrm{C} \mathrm{NMR}\left(100 \mathrm{MHz}, \mathrm{CD}_{3} \mathrm{OD}\right)$ : $\delta 169.1(-\mathrm{COOH}), 146.5(\mathrm{C}-3,-5), 139.8(\mathrm{C}-4), 121.4$ $(\mathrm{C}-1), 110.1(\mathrm{C}-2,-6), 52.4\left(4-\mathrm{OCH}_{3}\right)$.

2.4m Compound 13: Off white solid; APCI MS $m / z$ $169[\mathrm{M}-\mathrm{H}]^{+},{ }^{1} \mathrm{H}$ NMR $\left(400 \mathrm{MHz}, \mathrm{CD}_{3} \mathrm{OD}, \delta \mathrm{ppm}\right)$ : $7.05(\mathrm{~s}, 2 \mathrm{H}) ;{ }^{13} \mathrm{C}$ NMR $\left(75 \mathrm{MHz}, \mathrm{CD}_{3} \mathrm{OD}, \delta \mathrm{ppm}\right)$ : 172.4, 145.1, 138.3, 120.4, 108.6.

\subsection{In vitro antileishmanial activity}

The MTT viability assay was performed as described previously. ${ }^{16}$ Briefly, approximately $2 \times 10^{5}$ L. donovani promastigotes were plated in $200 \mu \mathrm{L}$ of RPMI1640 media $(\mathrm{pH}$ 7.2) in a flat-bottom 96-well culture microplate. Plate was incubated for $48 \mathrm{~h}$ at $24^{\circ} \mathrm{C}$. Compounds were added to the wells at different concentrations and the plate was again incubated for $48 \mathrm{~h}$ at $24^{\circ} \mathrm{C}$. MTT solution was added to each well to a final concentration of $400 \mu \mathrm{g} / \mathrm{mL}$, and the plates were incubated for $3-4 \mathrm{~h}$ at $37^{\circ} \mathrm{C}$. Cells were centrifuged at $3,000 \mathrm{~g}$ for $10 \mathrm{~min}$. Pellets were dissolved in $150 \mu \mathrm{L}$ of dimethyl sulphoxide (DMSO) and further incubated for $15 \mathrm{~min}$. The absorbance was read on an automated microplate reader (Powerpack 200; Biotek Instruments) at $540 \mathrm{~nm}$.

\subsection{HPLC analyses}

2.6a Sample preparation: A sample $(30 \mathrm{~g})$ of the dried leaves of $C$. maculata was placed in a Soxhlet extraction thimble and sequential extraction was carried out with $n$-hexane, dichloromethane, ethyl acetate and methanol for $24 \mathrm{~h}$ with each solvent. The extracts obtained were filtered to remove any plant particles and concentrated under vacuum to yield hexane, dichloromethane, ethyl acetate and methanol extracts.

For HPLC analysis, hexane, dichloromethane and ethyl acetate extracts were dissolved in acetonitrile: ethyl acetate (1:1) and the methanol extract was dissolved in methanol to make a concentration of $1 \mathrm{mg} / \mathrm{mL}$ and filtered through a $0.45 \mu$ PTFE syringe filter. Five $\mu \mathrm{L}$ of each extract was injected onto the HPLC column using an autosampler. 
2.6b Chromatographic conditions: Appropriate separation was achieved on $\mathrm{C}_{18}$ Phenomenex $(250 \times 4.6 \mathrm{~mm}$, $5 \mu$ ) column with a gradient of ACN (solvent A), water containing 2\% formic acid (solvent B) and ACN containing $1 \%$ formic acid (solvent $\mathrm{C}$ ) using the following program: $0-10 \min 5 \% \mathrm{~A}$ in $\mathrm{B}, 10-12 \min 20 \%$ $\mathrm{A}$ in $\mathrm{B}, 12-20 \min 20 \% \mathrm{~A}$ in $\mathrm{B}, 20-25 \min 30 \% \mathrm{~A}$ in $\mathrm{B}, 25-30 \mathrm{~min} 40 \% \mathrm{~A}$ in $\mathrm{B}, 30-35 \mathrm{~min} 50 \% \mathrm{~A}$ in B, 35-45 min 60\% A in B, 45-65 min $75 \%$ A in B, $65-70$ min $100 \%$ C, $70-85 \min 100 \%$ C, $85-87$ min $5 \%$ $\mathrm{A}$ in B, 87-95 min 5\% A in B. The flow rate was set at $1.5 \mathrm{~mL} / \mathrm{min}$ and the analytes were detected at $280 \mathrm{~nm}$. Sample injection volume was $5 \mu \mathrm{L}$.

2.6c Validation of HPLC method: Stock solutions $(1 \mathrm{mg} / \mathrm{mL})$ of standards $(\mathbf{1 - 7}, \mathbf{9 - 3 0})$ were prepared in ethyl acetate-acetonitrile (1:1) and diluted to appropriate concentrations for establishment of calibration curves. Six concentrations of the 29 standards were injected in triplicate and the calibration curves were constructed by plotting the peak areas against the concentration of each analyte.

The limit of detection (LOD) and limit of quantification (LOQ) under the above stated chromatographic conditions were determined on the basis of response at a signal-to-noise ratio $(\mathrm{S} / \mathrm{N})$ of 3 and 10 , respectively.

Intra- and inter-day variations were used to determine the precision of the HPLC method. A sample of $30 \mathrm{~g}$ of dried leaves of $C$. maculata was extracted and analysed as described in the sections above. Intra-day precision was performed by triplicate extraction and analysis on a single day. The inter-day precision was carried out on 3 different days. Variations were expressed as the relative standard deviations (RSD). The recovery test was used to evaluate the accuracy of this quantitation method. Accurate amounts of the 29 analytes were added to known amounts of ethyl acetate extract that was then dissolved in ethyl acetate-acetonitrile (1:1) and analysed. The average recoveries were calculated by the following formula: recovery $(\%)=100 \times$ (amount found-original amount)/amount spiked, with $\operatorname{RSD}(\%)=(\mathrm{SD} /$ mean $) \times 100 \%$.

\section{Results and discussion}

\subsection{Isolation, characterization and antileishmanial activity}

The in vitro antileishmanial activity of $n$-hexane, dichloromethane, ethyl acetate and methanol extracts of $C$. maculata prepared by sequential maceration revealed that the hexane and methanol extracts were active $\left(\mathrm{IC}_{50} 7.0\right.$ and $7.1 \mu \mathrm{g} / \mathrm{mL}$, respectively), ethyl acetate extract was moderately active $\left(\mathrm{IC}_{50}\right.$ $13.0 \mu \mathrm{g} / \mathrm{mL}$ ) and the chloroform extract was inactive.

Compounds $\mathbf{1}$ and $\mathbf{2}$ were obtained after semipreparative HPLC of yellowish crystals separated out of hexane extract of $C$. maculata leaves. ${ }^{1} \mathrm{H}$ and ${ }^{13} \mathrm{C}$ NMR of the two compounds were very similar and the molecular ion peaks in APCI MS showed a difference of 15 units indicating the loss of one methyl group. The ${ }^{1} \mathrm{H}$ NMR spectrum of $\mathbf{1}$ revealed the presence of a H-bonded hydroxyl group, a para substituted B ring, one aromatic A ring proton, two methoxyl groups and one $C$-methyl substituent. The combined information from the ${ }^{1} \mathrm{H}$ and ${ }^{13} \mathrm{C}$ NMR data confirmed that $\mathbf{1}$ was a flavone, unsubstituted in 3-position $\left(\delta_{\mathrm{H}} 6.59, \delta_{\mathrm{C}} 105.3\right)$. Ring B protons appeared as two doublets, for two protons each $\left(\delta 7.84\right.$ and 7.01) in ${ }^{1} \mathrm{H}$ NMR. This compound was identified as 5-hydroxy-7,4'-dimethoxy-6methylflavone (8-demethyl eucalyptin). In the spectral data of $\mathbf{2}$, an additional signal for a $C$-methyl group $\left(\delta_{\mathrm{H}} 2.39\right)$ appeared and the signal of the aromatic ring A proton $\left(\delta_{\mathrm{H}} 6.49\right)$ disappeared. Also, the signal for C-8 was shifted downfield $\left(\delta_{\mathrm{C}} 89.3\right.$ in $\mathbf{1}$ and 104.1 in 2). The structure of this compound was determined to be 5-hydroxy-7,4'-dimethoxy-6,8-dimethylflavone (eucalyptin).

Compound $\mathbf{3}$ was isolated as off-white solid from the methanol extract of leaves of $C$. maculata. A sodiated molecular ion peak was observed at $m / z 353[\mathrm{M}+\mathrm{Na}]^{+}$. A fragment peak due to loss of one methyl was present at $m / z 316\left[\mathrm{C}_{13} \mathrm{H}_{15} \mathrm{O}_{9}+\mathrm{H}\right]^{+}$. Another fragment peak at $\mathrm{m} / \mathrm{z} 202$ showed the presence of sodium adduct of a hexose sugar $\left[\mathrm{C}_{6} \mathrm{H}_{11} \mathrm{O}_{6} \mathrm{Na}\right]^{+}$. The IR absorption band at $3368 \mathrm{~cm}^{-1}$ indicated the presence of hydroxyl groups and the absorption band at $1654 \mathrm{~cm}^{-1}$ was indicative of a keto group. The signal of a quaternary carbon at $\delta 203.4$ in ${ }^{13} \mathrm{C}$ NMR spectrum confirmed the presence of a keto function in the molecule. ${ }^{13} \mathrm{C}$ NMR also showed signals due to phloroglucinol aromatic ring (between $\delta_{\mathrm{C}} 95-166$ ) and an acetyl group. The ${ }^{1} \mathrm{H}$ NMR spectrum presented two aromatic protons $(\delta 6.18$, d, $J=2.0 \mathrm{~Hz}$ and $5.94, \mathrm{~d}, J=2.0 \mathrm{~Hz})$ meta to each other. The presence of six ${ }^{13} \mathrm{C}$ NMR signals between $\delta 60$ to 105 were attributable to an $O$-glycosidically linked hexose residue. The hexose residue was considered to be $\beta$-D-glucopyranose because the chemical shifts of sugar carbon were in agreement with literature data. ${ }^{7}$ The coupling constant of anomeric proton ( $J=7.4 \mathrm{~Hz}$ ) confirmed $\beta$ configuration. Acidic hydrolysis of $\mathbf{3}$ gave glucose which was identified by comparison of TLC with an authentic sample. The spectrum indicated that $\mathrm{C}-2$ and $\mathrm{C}-6$ were non-equivalent, i.e., signals at $\delta 164.8$ and 161.2 , respectively. The $\mathrm{H}-3$ 
(C-3) and $\mathrm{H}-5(\mathrm{C}-5)$ signals were also non-equivalent, i.e., signals at $\delta 6.18$ (100.6) and 5.94 (93.9), respectively. This compound was characterized as 4,6dihydroxy-2- $O$-( $\beta$-D-glucopyranosyl)acetophenone or myrciaphenone $\mathrm{A}$.

Another compound (4) was isolated as a very minor component from the fractions containing myrciaphenone A. The spectral data of $\mathbf{4}$ indicated a close structural resemblance between the two compounds. ${ }^{1} \mathrm{H}$ and ${ }^{13} \mathrm{C}$ NMR showed signals for phloroacetophenone core as in myrciaphenone A. The presence of a galloyl group in the structure of $\mathbf{4}$ was suggested by a two proton singlet at $\delta 7.10$ in ${ }^{1} \mathrm{H}$ NMR and four characteristic carbon signals $(\delta 108.8,119.8,145.1,166.9)$ in ${ }^{13} \mathrm{C}$ NMR spectrum. The resonances between $\delta 3.48$ and $\delta 4.45$ were assigned to the protons of sugar moiety. The coupling constant of the anomeric proton $(\delta 5.07$, $\mathrm{d}, J=7.6 \mathrm{~Hz})$ in the ${ }^{1} \mathrm{H}$ NMR spectrum indicated $\beta$ configuration and from the other chemical shifts and coupling constants of the sugar moiety, it was clear that the sugar unit was $\beta$-D-glucopyranose. A considerable downfield shift in the signals of $\mathrm{H}-6^{\prime}$ ( $\delta 4.55$ and 4.45) of sugar moiety indicated the possible placement of galloyl functionality at $\mathrm{C}-6^{\prime}$ position. Finally, the HMBC spectrum ascertained the correlation of $\mathrm{H}-$ $6^{\prime}$ of the $\beta$-glucose moiety with $\mathrm{C}-1^{\prime \prime}$ of galloyl subunit. The structure of $\mathbf{4}$ was confirmed to be 4,6-dihydroxy$2-O$-[ $\beta$-D-(6"-galloyl)glucopyranosyl]acetophenone or myrciaphenone B. ${ }^{8}$

The other isolated compounds were characterized as quercetin-3-O- $\beta$-D-xylopyranoside (5), myricetin3- $O$ - $\alpha$-L-rhamnopyranoside (6), quercetin-3- $O-\beta$-Dgalactopyranoside (7), quercetin-3- $O-\beta$-D-glucopyranoside (8), quercetin-3- $O$ - $\alpha$-L-rhamnopyranoside (9), syringic acid (10), gallic acid-3-methyl ether (11), gallic acid-4methyl ether (12) and gallic acid (13) after the comparison of their physico-chemical and spectroscopic data with that reported in the literature (for ${ }^{1} \mathrm{H}$ and ${ }^{13} \mathrm{C}$ NMR data of compounds 1-9 refer table 1a and 1b). Except for compounds $\mathbf{1}$ and $\mathbf{2}$, all the other compounds are reported for the first time from this species.

Isolated flavonoids and phenolic glycosides were evaluated for their antileishmanial activity in vitro. The results (table 2) of this assay suggested that glycosylation was necessary for high activity. The flavonoid glycosides (6-9) were more active than the other compounds tested whereas aglycones, $\mathbf{1}$ and $\mathbf{2}$ were inactive and less active, respectively. Amongst the flavonoid glycosides, compound 5, where the glycone portion was a deoxy sugar i.e., xylose was much less active than the compounds containing D-glucose, D-galactose and L-rhamnose. In the case of myrciaphenone A (3) and B (4), the inhibition of promastigotes shown by 3
Table 2. In vitro antileishmanial activity of compounds isolated from C. maculata extracts.*

\begin{tabular}{lc}
\hline Compound & $\mathrm{IC}_{50}(\mu \mathrm{M})$ \\
\hline 8-Demethyl eucalyptin (1) & $\mathrm{NA}$ \\
Eucalyptin (2) & $11.0 \pm 1.4$ \\
Myciaphenone A (3) & $10.0 \pm 1.4$ \\
Myciaphenone B (4) & $\mathrm{NA}$ \\
Quercetin-3- $O$ - $\beta$-D-xylopyranoside (5) & $24.5 \pm 7.7$ \\
Myricetin-3- $O$ - $\alpha$-L-rhamnopyranoside (6) & $7.5 \pm 2.1$ \\
Quercetin-3- $O$ - $\beta$-D-galactopyranoside (7) & $6.9 \pm 0.3$ \\
Quercetin-3- $O$ - $\beta$-D-glucopyranoside (8) & $7.25 \pm 0.3$ \\
Quercetin-3- $O$ - $\alpha$-L-rhamnopyranoside (9) & $8.5 \pm 4.9$ \\
Miltefosine (Std.) & $10.0 \pm 3.0$
\end{tabular}

*Results are expressed as mean \pm SD of two independent experiments performed in triplicate

NA: Not active

was equivalent to that of the standard drug miltefosine whereas $\mathbf{4}$, the galloylated counterpart of $\mathbf{3}$ was completely inactive, again suggesting a possible role of the sugar moiety in the bioactivity of compounds in this assay.

\subsection{HPLC analyses}

3.2a Preparation of extracts: The extraction conditions and related parameters can lead to significant differences and variations in any quantitative analyses. Therefore, it was important to select one specific method of extraction for the phytochemical analysis of C. maculata. Sequential Soxhlet extraction was chosen for preparing extracts as it promised maximum extraction of the compounds of low, medium and high polarities. From a $30 \mathrm{~g}$ sample of dried leaves of C. maculata, $906 \mathrm{mg}$ of hexane, $1231 \mathrm{mg}$ of chloroform, $1107 \mathrm{mg}$ of ethyl acetate and $3689 \mathrm{mg}$ of methanol extracts, respectively, were obtained after sequential Soxhlet extraction.

3.2b Optimization of HPLC conditions: Recently, we have reported an HPLC-PDA method for simultaneous quantitation of 19 compounds belonging to different chemical classes to facilitate quantitative comparison amongst eucalypts. ${ }^{15}$ This method used a gradient of acetonitrile and 2\% aqueous formic acid for the separation of compounds. In the present study, we have improved upon that method to incorporate more plant constituents so as to increase the applicability of the method. Some of the phenolic acids (10-13) were isolated from the methanol extract of $C$. maculata, so, the gradient program was modified to detect/quantify more 
Jasmeen Sidana et al.

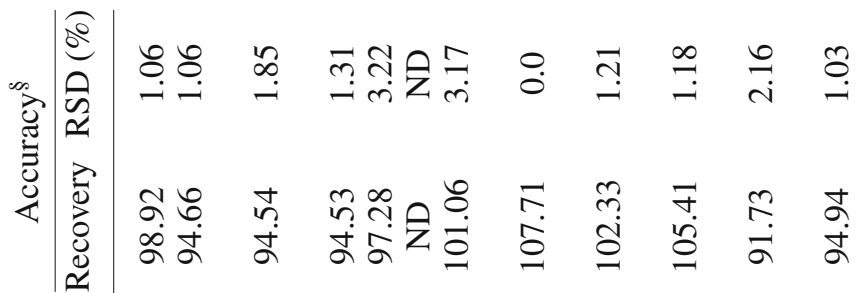

호

惫

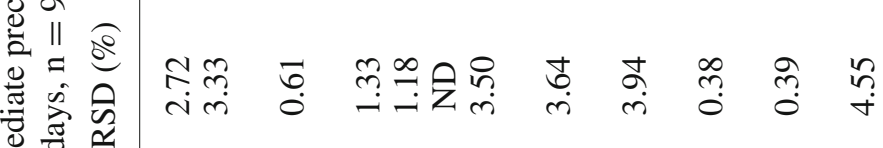

E

$\stackrel{\stackrel{\Xi}{\Xi}}{=}$

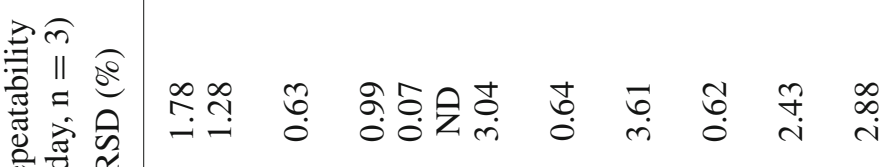
$\approx=$

苟

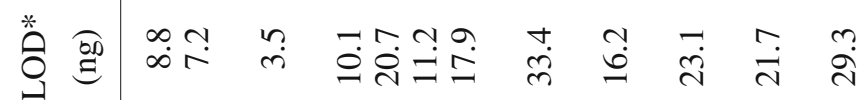

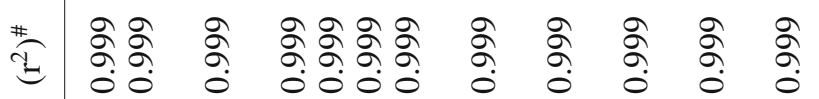

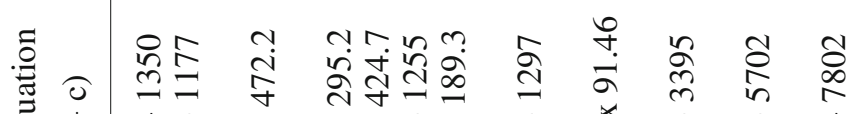

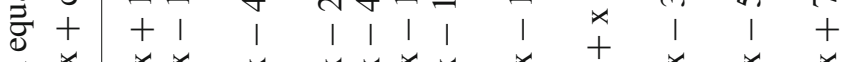

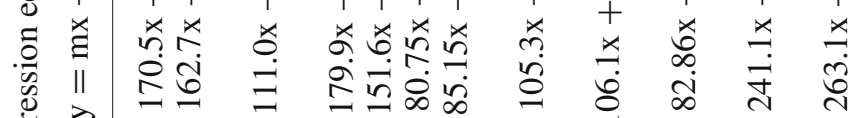

$\underset{0}{0} \gtrsim$

$\|$

(I)

II

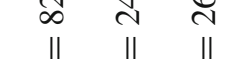

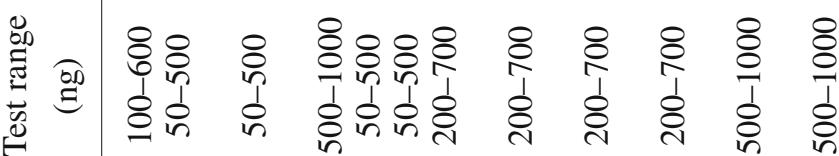

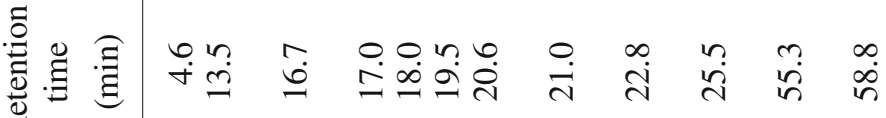

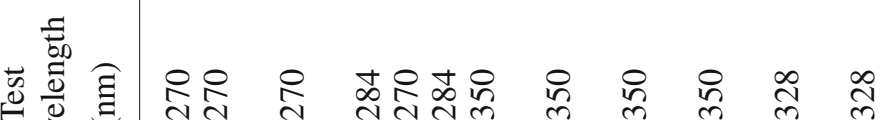

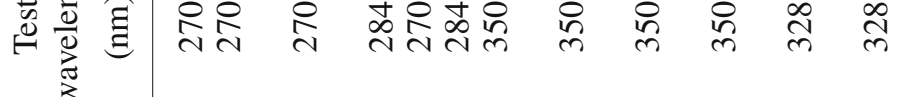

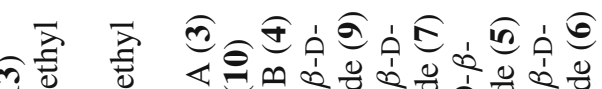

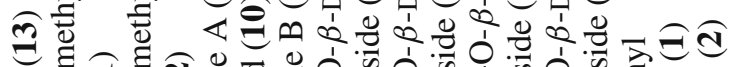

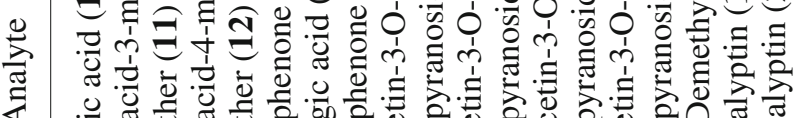

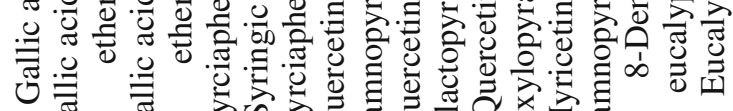

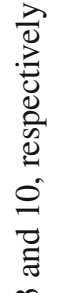

4

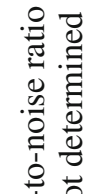

咅

需㝋

os

寻

乎总

is 80

.ี

旁

?로

.

స్త్రి

$\cong$

节

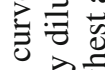

둥 $\frac{200}{0}$

旸

䨌

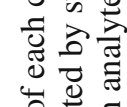

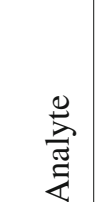

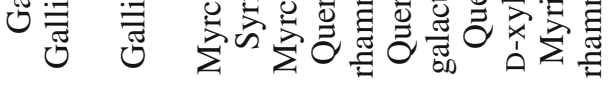


compounds of this class (15-17). Particularly, the initial ratio of the stronger solvent i.e., $\mathrm{ACN}$ was reduced and gradient time was increased so that highly polar phenolic acids could be separated.

After trying several solvent systems and gradients, a solvent system consisting of ACN (solvent A), water with $2 \%$ formic acid (solvent B), ACN with $1 \%$ formic acid (solvent $\mathrm{C}$ ) in gradient mode (as described in "chromatographic conditions') was found to be optimum. Initially, a binary gradient of A and B was used from 0 to $65 \mathrm{~min}$. This gradient allowed the separation of eucalyptin (2), a methylated flavonoid and jensenone (23), a formylated phloroglucinol which, despite their structural differences, were eluting at same RT in several other solvent systems and gradient programs (though baseline resolution was not achieved in this gradient but owing to the differences in $\lambda_{\max }, 328$ for eucalyptin and 266 for jensenone, qualitative analysis of samples containing both the compounds was possible). From 65 to $70 \mathrm{~min}$, the proportions of solvents $\mathrm{A}$ and $\mathrm{B}$ were decreased and that of $\mathrm{C}$ was increased until $100 \%$ at 70 min. The $100 \%$ concentration of $\mathrm{C}$ was maintained for $15 \mathrm{~min}$. This allowed the resolution of euglobals (25, 27-30) and sideroxylonal A (26) that otherwise was not
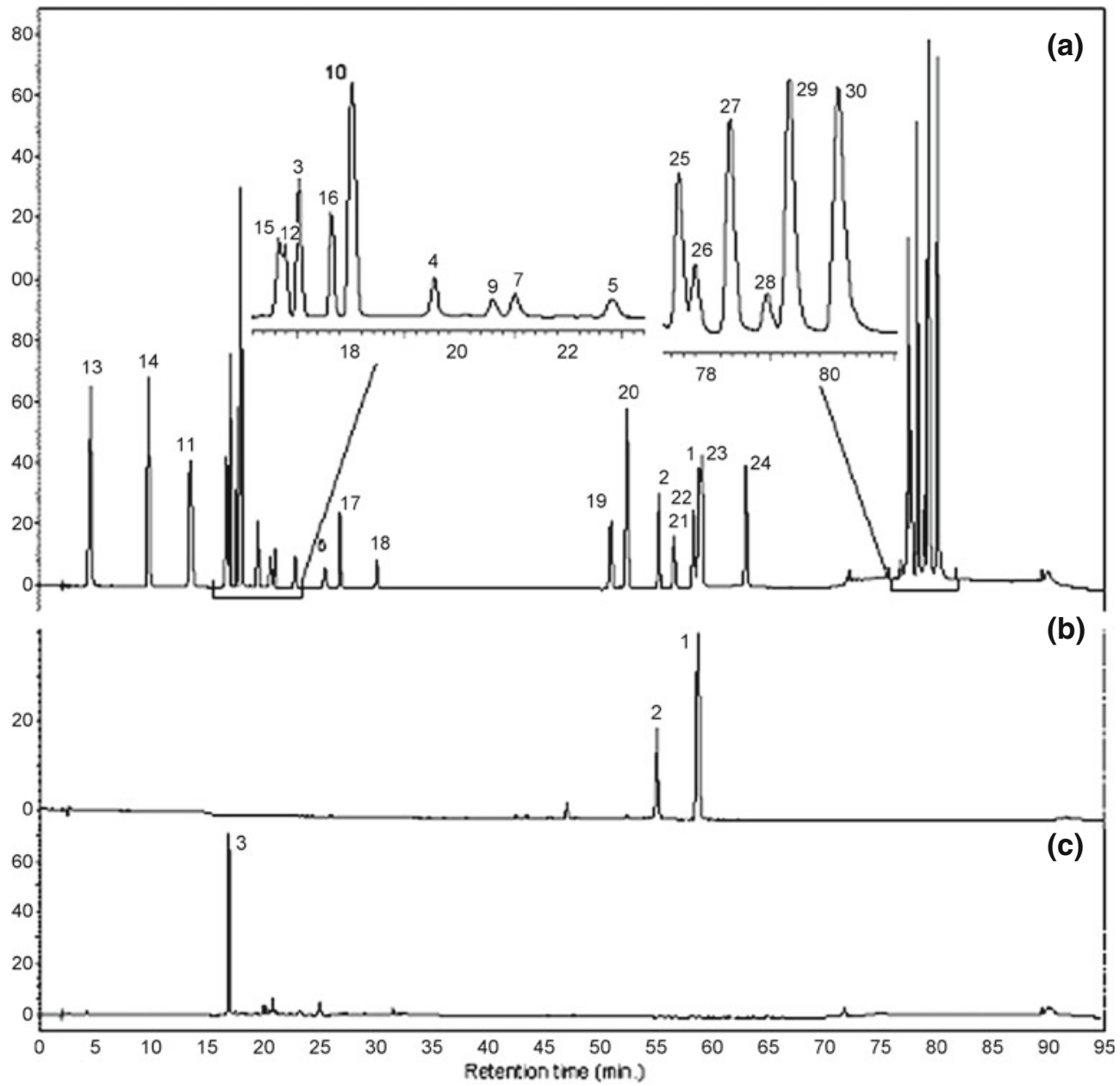

Figure 2. HPLC chromatogram (at $280 \mathrm{~nm}$ ) of (a) mixed standard solution, 13: gallic acid (4.63 $\mathrm{min})$; 14: protocatechuic acid $(9.76 \mathrm{~min})$; 11: gallic acid-3-methyl ether (13.52 $\mathrm{min})$; 15: chlorogenic acid (16.60 $\mathrm{min})$; 12: gallic acid-4-methyl ether (16.78 $\mathrm{min})$; $\mathbf{3}$ : myrciaphenone A (17.04 $\mathrm{min})$; 16: caffeic acid $(17.63 \mathrm{~min})$; 10: syringic acid (18.03 $\mathrm{min})$; 4: myrciaphenone B (19.53 min); 9: quercetin-3- $O$ - $\alpha$-L-rhamnopyranoside (20.60 min); 7: quercetin-3- $O$ - $\beta$-D-galactopyranoside (21.00 min); 5: quercetin-3- $O$ - $\beta$-D-xylopyranoside (22.8 $\mathrm{min})$; 6: myricetin-3- $O$ - $\alpha$-L-rhamnopyranoside $(25.50 \mathrm{~min})$; 17: 2-hydroxy cinnamic acid $(26.88 \mathrm{~min})$; 18: syncarpic acid $(30.08 \mathrm{~min})$; 19: flavesone $(50.99 \mathrm{~min})$; 20: miniatone (52.43 min); 1: 8-demethyl eucalyptin (55.27 min); 21: grandinol (56.63 min); 22: 8demethyl kalmiatin (58.39 min); 2: eucalyptin (58.88 min); 23: jensenone (59.14 min); 24: leptospermone (63.06 min); 25: euglobal G1 (77.52 min); 26: sideroxylonal A (77.79 $\mathrm{min})$; 27: euglobal G2 (78.36 min); 28: euglobal Bl-1 (78.95 min); 29: euglobal G3 (79.32 min) and 30: euglobal G4 (80.09 $\mathrm{min})$; (b) hexane extract; (c) ethyl acetate extract. 
achieved. Another mobile phase with solvents $\mathrm{C}$ and B (keeping the gradient program same as above) was tested but eucalyptin and jensenone were eluted as a single peak in this system. The gradient program with the solvents A, B and C was used for all analyses. One disadvantage of this method is the co-elution of quercetin3- $O$ - $\beta$-D-galactopyranoside (7) and quercetin-3- $O-\beta$ D-glucopyranoside (8). For the quantitation of $\mathbf{7}$ and $\mathbf{8}$, calibration curve of $\mathbf{7}$ was constructed and both $\mathbf{7}$ and $\mathbf{8}$ were quantified in total.

3.2c Method validation: The proposed method was validated to determine the linearity, LOD, LOQ, intraand inter-day precisions and accuracy. The calibration curves for compounds (1-7, 9-13) were obtained with concentrations in six increments. The correlation coefficient values $\left(r^{2}=0.999\right)$ indicated the appropriate correlation between concentration and the corresponding peak areas. LOD and LOQ for all the analytes were determined by diluting the standard stock solutions of the corresponding compounds sequentially. The LOD $(\mathrm{S} / \mathrm{N}=3)$ and LOQ $(\mathrm{S} / \mathrm{N}=10)$ for the compounds quantified were in the range of 3.5-33.4 ng and $12-97.8 \mathrm{ng}$, respectively (table 3 ). The HPLC method developed showed good reproducibility for the quantitation of 12 compounds, with intra- and inter-day variations of these compounds less than 3.6\% (RSD) and $4.6 \%$ (RSD), respectively. Also, this method was found to be accurate with the overall recovery of $91.7-107.7 \%$ (RSD range 0.0-3.22\%) (table 3). These results establish that the developed method is sensitive, precise and accurate with respect to the plant constituents studied and can be applied more widely for qualitative and quantitative analysis of eucalypt matrices. 3.2d Analysis of samples and quantitation: The extracts of $C$. maculata leaves prepared by sequential Soxhlet extraction were analysed by the developed method. Of the 29 compounds used in method development, only two were detected in hexane and chloroform extracts and ten compounds were found to be present in ethyl acetate and methanol extracts. The HPLC chromatogram of 29 mixed standards along with the chromatograms of hexane and ethyl acetate extracts are shown in figure 2 and the contents of the detected constituents in the respective extracts are presented in table 4.

The results of the HPLC quantitation were consistent with the biological activity results. In the in vitro antileishmanial assay, hexane and methanol extracts were most active. In case of hexane extract, demethyl eucalyptin (1) and eucalyptin (2) were found to be the major constituents, present at 2.16 and $2.87 \%$, respectively. The methanol extract showed the presence of active flavonoid glycosides. Myrciaphenone $\mathrm{A}\left(\mathbf{3}, \mathrm{IC}_{50}\right.$ $10 \mu \mathrm{M})$ was found to be the major constituent of the ethyl acetate extract. Myrciaphenone B could not be detected in any of the extracts up to a loading of $5000 \mathrm{ng}$. None of the active (or inactive) compounds could be detected in the chloroform extract.

\subsection{Chemotaxonomical importance of the study}

The genus Eucalyptus encompasses about 800 species grouped into 13 different informal subgenera. ${ }^{17} \mathrm{~W} \mathrm{E}$ Hillis studied the variation of the polyphenol content in different eucalypts as a marker in their chemosystematic studies. ${ }^{18-22}$ More recently, Eschler et al. asserted that formylated phloroglucinol compounds (FPCs) are

Table 4. The contents of the studied compounds in three extracts of dry leaves of C. maculata.

\begin{tabular}{|c|c|c|c|c|}
\hline \multirow[b]{2}{*}{ Sl. No. } & \multirow[b]{2}{*}{ Compound } & \multicolumn{3}{|c|}{ Content $(\%)^{\mathrm{a}}$} \\
\hline & & Hexane extract & Ethyl acetate extract & Methanol extract \\
\hline 1 & Gallic acid (13) & - & $3.17 \pm 0.09$ & $1.20 \pm 0.03$ \\
\hline 2 & Gallic acid-3-methyl ether (11) & - & - & $1.73 \pm 0.06$ \\
\hline 3 & Gallic acid-4-methyl ether (12) & - & - & $1.95 \pm 0.01$ \\
\hline 4 & Myrciaphenone A (3) & - & $8.26 \pm 0.78$ & $1.38 \pm 0.14$ \\
\hline 5 & Syringic acid (10) & - & - & $2.66 \pm 0.03$ \\
\hline 6 & Quercetin 3-O- $\beta$-D-rhamnopyranoside (9) & - & $1.71 \pm 0.16$ & $0.41 \pm 0.05$ \\
\hline 7 & Quercetin 3-O- $\beta$-D-galactopyranoside (7) ${ }^{\mathrm{b}}$ & - & $0.49 \pm 0.02$ & $0.46 \pm 0.03$ \\
\hline 8 & Quercetin 3-O- $\beta$-D-xylopyranoside (5) & - & $0.32 \pm 0.01$ & $0.05 \pm 0.01$ \\
\hline 9 & Myricetin 3-O- $\beta$-D-rhamnopyranoside (6) & - & $2.24 \pm 0.20$ & $0.40 \pm 0.06$ \\
\hline 10 & 8-Demethyl eucalyptin (1) & $2.16 \pm 0.15$ & - & - \\
\hline 11 & Eucalyptin (2) & $2.87 \pm 0.26$ & - & - \\
\hline
\end{tabular}

${ }^{\mathrm{a}}$ Content $=$ mean \pm s.d. $(n=3)$; ${ }^{\mathrm{b}}$ total content of 7 and 8 based on the calibration curve of quercetin 3 -O- $\beta$-Dgalactopyranoside (7); -, not detected 
found more abundantly in the sub-genera Symphyomyrtus and Eudesmia whereas there is a notable lack of FPCs in the sub-genera Monocalyptus, Idiogenes, Blakella and several species of Corymbia. ${ }^{23}$ So, to confirm the presence or absence of FPCs in Corymbia maculata, we undertook phytochemical investigations of this plant.

Our results show that there is a complete absence of the tested FPCs in all four extracts of $C$. maculata. Also, none of the tested 'non-formylated' phloroglucinols (miniatone and triketones) could be detected in these extracts. Though this study was done on a single bulk sample of $C$. maculata originating from four individual trees, it supports the results of earlier experiments done by Eschler et al. ${ }^{23}$

\section{Conclusions}

The phytochemical screening of $C$. maculata resulted in the isolation of thirteen compounds from hexane and methanol extracts of the dried leaves. Flavonoid glycosides and a phloroglucinol glycoside were the active antileishmanial compounds. The developed HPLCPDA method can be applied for the simultaneous quantitation of phytoconstituents of different chemical classes. This method was applied to detect and quantify twelve compounds in the extracts of $C$. maculata leaves.

\section{Acknowledgements}

Authors thank the Director, NIPER for support and Dr Ian Wallis for assistance in collecting Corymbia maculata foliage.

\section{References}

1. WHO technical report series, Leishmaniasis (2010) Retrived from WHO website: http://whqlibdoc.who.int/ trs/WHO_TRS_949_eng.pdf

2. Bharate S B, Khan S I, Yunus N A M, Chauthe S K, Tekwani B L, Jacob M R, Khan I A and Singh I P 2007 Bioorg. Med. Chem. 1587

3. Bharate S B, Khan S I, Tekwani B L, Jacob M R, Khan I A and Singh I P 2008 Bioorg. Med. Chem. 161328

4. Sidana J, Singh S, Arora S K, Foley W J and Singh I P 2011 Fitoterapia 821118

5. Takahashi T, Kokubo R and Sakaino M 2004 Lett. Appl. Microbiol. 3960

6. Lamberton J A 1964 Aust. J. Chem. 17692

7. Suksamrarn A, Eiamong S, Piyachaturawat P and Byrne L T 1997 Phytochemistry 45103

8. Chosson E, Chaboud A, Chulia A J and Raynaud J 1998 Phytochemistry 4787

9. Lu Y and Foo L Y 1997 Food Chem. 59187

10. David J M, Cruz F G, Guedes M L S and Chavez J P 1996 J. Braz. Chem. Soc. 7115

11. Wettasinghe M, Shahidi F, Amarowicz R and Abou-Zaid M M 2001 Food Chem. 7549

12. Ali Z, Ahmad V U, Zahid M and Tareen R B 1998 Phytochemistry 481271

13. Saxena G, McCutcheona A R, Farmerb S, Towersa G H N and Hancock R E W 1994 J. Ethnopharmacol. 4295

14. Singh P P, Ambika and Chauhan S M S 2009 Food Chem. 1141069

15. Sidana J, Foley W J and Singh I P 2012 Phytochem. Anal. 23483

16. Mosmann T 1983 J. Immunol. Methods 6555

17. Brooker M I H 2000 Aust. Syst. Bot. 1379

18. Hillis W E 1966 Phytochemistry 51075

19. Hillis W E 1967a Phytochemistry 6259

20. Hillis W E 1967b Phytochemistry 6275

21. Hillis W E 1967c Phytochemistry 6373

22. Hillis W E 1967d Phytochemistry 6845

23. Eschler B M, Pass D M, Willis R and Foley W J 2000 Biochem. Syst. Ecol. 28813 